\title{
Seasonal effects on gene expression, cleavage timing, and developmental competence of bovine preimplantation embryos
}

\author{
M Gendelman ${ }^{1}$, A Aroyo ${ }^{1,2}$, S Yavin ${ }^{1,2}$ and Z Roth ${ }^{1}$ \\ ${ }^{1}$ Department of Animal Sciences, Robert H. Smith Faculty of Agriculture, Food and Environment, The Hebrew \\ University, Rehovot 76100, Israel and ${ }^{2}$ Institute of Animal Science, Agricultural Research Organization, The Volcani \\ Center, PO Box 6, Bet Dagan 50250, Israel
}

Correspondence should be addressed to Z Roth; Email: roth@agri.huji.ac.il

\begin{abstract}
We examined the association between season and expression of genes involved in early embryonic development with an emphasis on cleavage rate and timing of the first embryonic cleavage. In Exp. 1, oocytes were aspirated during the cold (Dec-Apr) and hot (May-Nov) seasons. Matured oocytes were chemically activated and cultured in vitro. The developmental peak to the two- and four-cell stages occurred earlier, with a higher proportion of first-cleaved embryos, during the cold season relative to the hot season $(P<0.01)$. In Exp. 2, a time-lapse system was employed to characterize the delayed cleavage noted for the hot season. Cleavage to the two-cell stage occurred in two distinct waves: early cleavage occurred between 18 and $25 \mathrm{~h}$ post activation, and late cleavage occurred between 27 and $40 \mathrm{~h}$ post activation. In Exp. 3, oocytes were aspirated during the cold and hot seasons, matured in vitro, fertilized, and cultured for 8 days. In each season, early- and late-cleaved two-cell stage embryos were collected. Total RNA was isolated, and semi-quantitative and real-time PCRs were carried out with primers for GDF9, POU5F1, and GAPDH using 185 rRNA as the reference gene. In both seasons, the expression of all examined genes was higher $(P<0.05)$ in early- versus late-cleaved embryos. POU5F1 expression was higher $(P<0.05)$ in early-cleaved embryos developed in the cold season versus the hot season counterparts. The findings suggest a deleterious seasonal effect on oocyte developmental competence with delayed cleavage and variation in gene expression.
\end{abstract}

Reproduction (2010) 140 73-82

\section{Introduction}

Reduced reproductive performance of lactating cows during the summer has been well documented and mostly attributed to the sensitivity of the ovarian tissues to elevated temperature (Wolfenson et al. 2000, Roth et al. 2008). Hyperthermia can directly disrupt follicular function (Roth et al. 2000) as expressed by altered follicular development, depressed dominance, and impaired follicular steroidogenesis and gonadotropin secretion (Wolfenson et al. 2000). Alternatively, perturbation in the physiology of the follicle-enclosed oocyte can potentially lead to its reduced competence for fertilization and subsequent development.

Mammalian oocytes are arrested in the prophase stage of the first meiotic division, and acquire their meiotic competence and fertilization potential in a stepwise manner (Masui 2001). As a result, they are potentially exposed to various environmental stressors during follicular development. Oocytes harvested from cows during the summer exhibit reduced embryonic developmental competence following IVF (Rocha et al. 1998, Al-Katanani et al. 2002) or chemical activation (Zeron et al. 2001). A seasonal study, performed from late summer to early winter, indicated that a period of two to three estrous cycles is required for recovery from heat damage and appearance of competent oocytes (Roth et al. 2001). Similarly, induction of maternal hyperthermia in mice carried over through three pregnancy cycles (Aroyo et al. 2007), suggesting that not only the individual ovulated oocyte, but also the ovarian pool of oocytes can be damaged during heat exposure. Nevertheless, the mechanism underlying the disruption in oocyte developmental competence is not entirely clear, and therefore, the changes that occur at the molecular and cellular levels in the oocytes in response to heat stress need to be investigated further.

Changes in gene expression are an integral part of the cellular response to heat shock. While the genes encoding heat shock proteins (HSPs) have been best studied, it has recently become apparent that thermal stress also affects a substantial number of genes which are not directly associated with HSPs (Sonna et al. 2002). Therefore, the current study examines the association between seasons and the expression of genes playing an essential role during oogenesis, folliculogenesis, or early embryonic development. Among these genes is growth differentiation factor 9 (GDF9), a germ-cell marker and 
member of the large transforming growth factor $\beta$ superfamily (TGFB; McPherron \& Lee 1993). GDF9 plays a pivotal role in folliculogenesis since homozygous knockout female mice are sterile due to blockage of follicles at the primary stage (Dong et al. 1996). It also regulates cumulus cell function in the preovulatory period (Gui \& Joyce 2005), and therefore, it might be involved in oocyte maturation. Another examined gene is POU5F1 (also known as OCT4), a member of the POU family of transcriptional activators which contain the DNA-binding POU domain (Ryan \& Rosenfeld 1997). The POU5F1 gene is essential for the maintenance of totipotency/pluripotency in embryonic stem cells and primordial germ cells: a progressive loss of POU5F1 has been associated with loss of pluripotency (Okamoto et al. 1990, Yeom et al. 1996). The current study examines the association between elevated temperature and expression of genes involved in oocyte maturation early in embryonic development, with an emphasis on cleavage timing of the two first embryonic developmental deviations.

\section{Results}

Experiment 1: seasonal effects on cleavage timing and developmental competence of bovine oocytes following chemical activation

Oocytes were collected during the cold $(n=2218)$ and hot $(n=3198)$ seasons. The number of follicles $(3-8 \mathrm{~mm}$ in diameter) per ovary collected during the cold season was higher than that collected in the hot
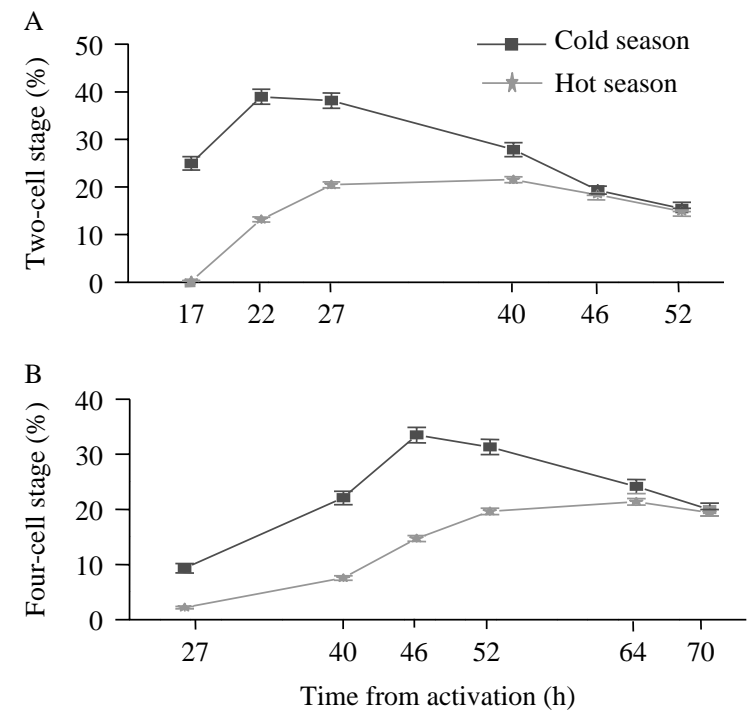

Figure 1 Cleavage timing of bovine embryos into the two- and four-cell stages. Oocytes were aspirated and activated during cold (Dec-Apr; squares) and hot (May-Nov; stars) seasons. The proportion of embryos that developed to the two-cell stage (A) and that developed to the four-cell stage (B) was recorded at 17, 22, 27, 40, 46, 52, 64, and $72 \mathrm{~h}$ post activation. Results are presented as means \pm s.E.M.; seasonal effect, $P<0.01$. season $(29.0 \pm 1.0$ vs $24.0 \pm 1.0$ respectively; $P<0.03)$. The average number of oocytes aspirated in the cold season was higher than that aspirated in the hot season $(8.5 \pm 0.5$ vs $6.0 \pm 0.5$ respectively; $P<0.01)$. The proportion of parthenotes that cleaved to the two- to four-cell stage was higher in the cold season than in the hot season ( $72 \pm 0.9$ vs $46 \pm 0.8 \%$ respectively; $P<0.01$ ). The developmental peak of the two-cell stage embryo was higher (39 vs $21 \% ; P<0.01)$ and occurred earlier (22-27 vs $40 \mathrm{~h}$ post activation; Fig. 1A) in the cold versus hot season respectively. Similarly, the developmental peak of the four-cell stage was higher (33 vs $21 \% ; P<0.01)$ and occurred earlier $(46-52$ vs 52-70 h post activation; Fig. 1B) in the cold versus hot season respectively.

\section{Experiment 2: using time-lapse system to evaluate the accurate cleavage timing}

This experiment was performed during two consecutive hot seasons using a time-lapse system. In the first year, 137 bovine oocytes, in two replicates, were examined (Fig. 2A). In the second year, 171 oocytes, in four replicates, were examined (Fig. 2B). Time-lapse examination of the first embryonic division revealed that during the hot season, embryos cleave in two distinct waves. The first cleavage wave occurred between 18 and $25 \mathrm{~h}$ post activation and the second cleavage wave occurred between 26 and $42 \mathrm{~h}$ post activation.
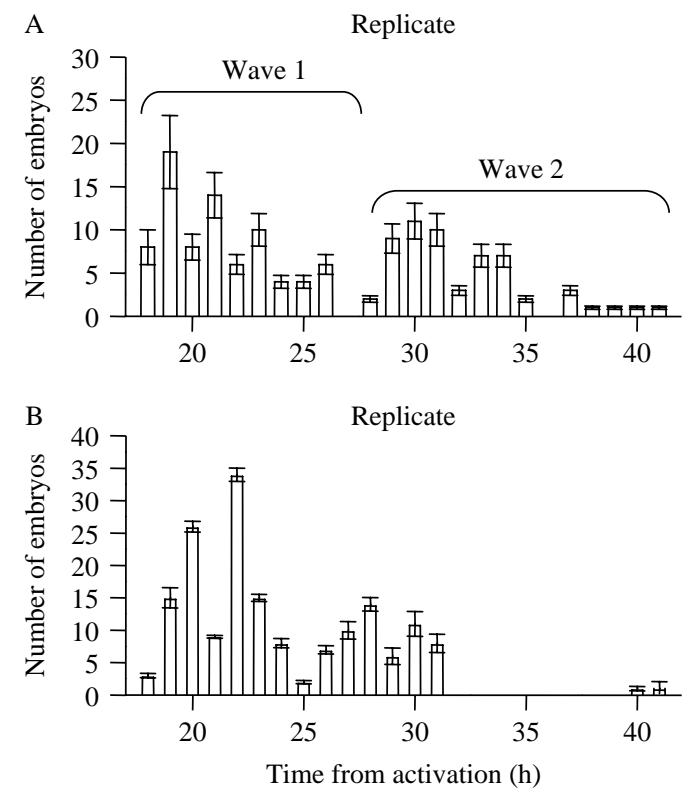

Figure 2 First cleavage division into the two-cell stage of bovine parthenotes during two consecutive hot seasons (A - two replicates, $n=137$ oocytes, and B - four replicates, $n=171$ oocytes respectively). Oocytes were activated and observed by EmbryoGuard time-lapse system that was pre-programmed to take photos at 1-h intervals. Embryos cleaved in two distinct waves: the first wave occurred between 18 and $25 \mathrm{~h}$ post activation, and the second wave occurred between 26 and $42 \mathrm{~h}$ post activation. Results are presented as means \pm s.E.M. 


\section{Experiment 3: seasonal variation in gene expression in two-cell stage embryos}

The percentage of embryos developed to the blastocyst stage was higher in the cold season than in the hot season $(23.0 \pm 2.3$ vs $9.0 \pm 3.5 \%$ respectively; $P<0.05)$. The percentage of embryos that cleaved to the two- to four-cell stage ( $42 \mathrm{~h}$ post fertilization) did not differ between seasons $(80.0 \pm 4.5$ vs $73.3 \pm 3.2 \%$ respectively; Fig. 3). However, the proportion of two-cell stage embryos recorded in the hot season was twofold higher than that of the four-cell stage embryos, suggesting a delay in the second embryonic division (Fig. 4). In addition, the proportion of embryos developed to the four-cell stage (42 $\mathrm{h}$ post fertilization) was higher in the cold season than in the hot season (Fig. 4).

\section{Seasonal effect on gene expression in two-cell stage embryos}

Examination of gene expression in both early (27 h post fertilization) and late (42 $\mathrm{h}$ post fertilization) first-cleaved embryos (i.e. two-cell stage embryos) revealed higher expression of GDF9 and POU5F1 in the early- versus late-cleaved embryos in both the cold and hot seasons (Figs $5 \mathrm{~A}$ and $\mathrm{B}$ and $6 \mathrm{~A}$ and $\mathrm{B}$ ). With respect to $G A P D H$, while semi-quantitative PCR did not reveal any differences in its expression between early- and latecleaved embryos (Figs 5A and 6A), real-time PCR, which is a more sensitive method, demonstrated a significant difference (Figs 5B and 6B). Therefore, GAPDH was not used as a reference gene for PCR analysis. Instead, the $18 S$ rRNA gene was used as an internal reference since it was expressed at similar levels in both early- and latecleaved embryos, in both seasons. A comparison of gene expression in early-cleaved embryos revealed higher expression of POU5F1 in the cold versus hot season, without any effect on GDF9 or GAPDH expressions (Fig. 7). No seasonal variations in gene expression were noted for late-cleaved embryos (data not shown).

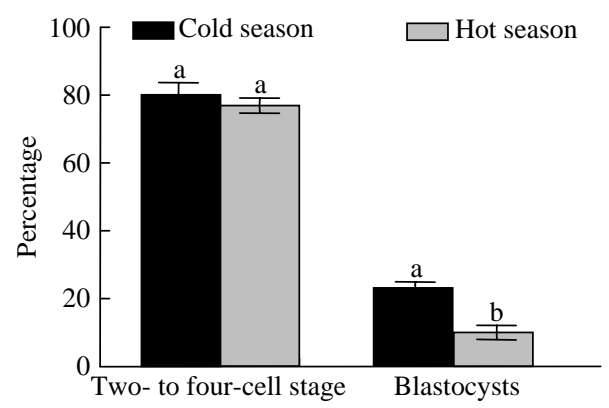

Figure 3 Seasonal effects on oocyte developmental competence. The proportion of oocytes cleaved to the two- to four-cell stage, $42 \mathrm{~h}$ post fertilization, and the proportion of embryos that developed to the blastocyst stage 8 days post fertilization are presented. Data are presented as means \pm S.E.M.; ${ }^{\text {a,b }}$ different superscripts indicate seasonal effect within embryonic stages, $P<0.05$.

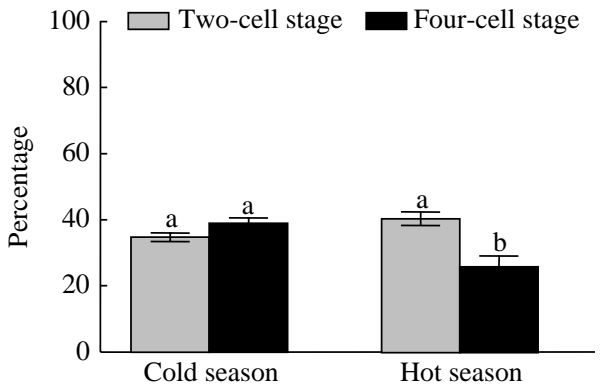

Figure 4 Seasonal variation in embryonic-stage distribution. The proportion of oocytes that were fertilized and cleaved to two- and four-cell stages at $42 \mathrm{~h}$ post fertilization is presented. Data are presented as means \pm s.E.M.; ${ }^{\text {a,b }}$ different superscripts indicate seasonal effect between and within embryonic stages, $P<0.05$.

\section{Discussion}

Season-induced disruption in the developmental competence of bovine oocytes appears to involve more than one mechanism. The current study indicates that the adverse effect of summer thermal stress on embryonic development is associated with seasonal variation in the expression of genes involved in oocyte maturation and early embryonic development. These alterations were also associated with delayed cleavage of the two first
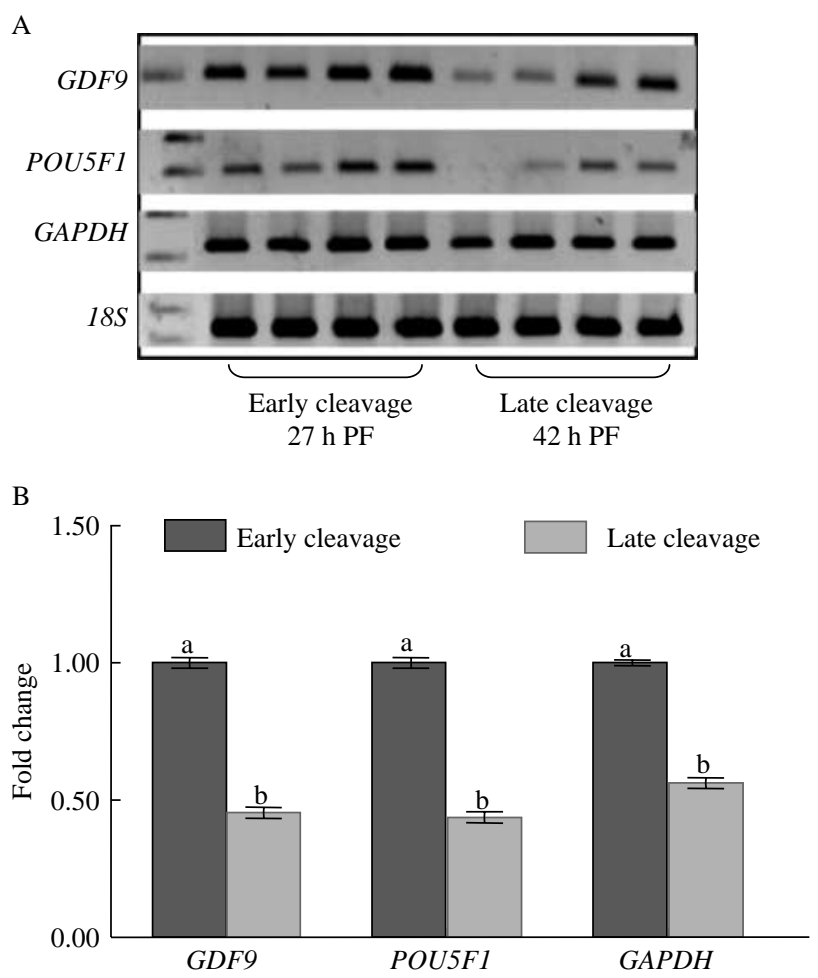

Figure 5 Transcript levels of GDF9, POU5F1, and GAPDH in both early- (27 h post fertilization (PF)) and late-cleaved (42 h PF) embryos to the two-cell stage in the cold season. Data from semi-quantitative PCR (A) and real-time PCR (B) are presented as means \pm s.E.M.; ${ }^{a, b}$ different superscripts indicate cleavage timing effect within genes, $P<0.05$. 


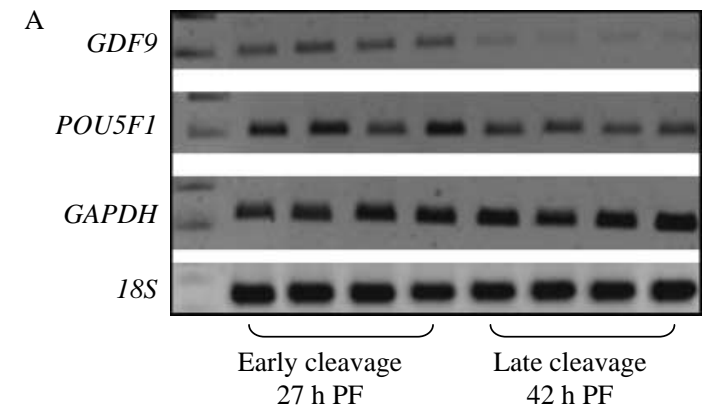

B

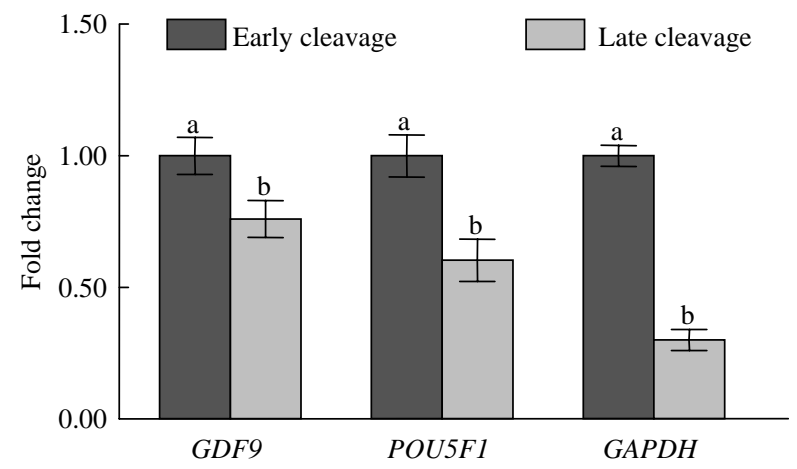

Figure 6 Transcript levels of GDF9, POU5F1, and GAPDH in both early- (27 h post fertilization (PF)) and late-cleaved (42 h PF) embryos to the two-cell stage in the hot season. Data from semi-quantitative PCR (A) and real-time PCR (B) are presented as means \pm S.E.M.; ${ }^{a, b}$ different superscripts indicate cleavage timing effect within genes, $P<0.05$.

embryonic deviations and decreased embryonic development to the two- and four-cell stage followed by a reduced proportion of embryos developing to the blastocyst stage.

\section{Early cleavage and cleavage timing}

Findings of the present study indicated delayed cleavage timing for both bovine parthenotes (Exp. 1) and in vitro derived embryos (Exp. 3) which developed from oocytes collected during the hot season. In the cold season, the developmental peak to the two-cell stage was higher and occurred about $13 \mathrm{~h}$ earlier than that in the hot season. A similar delay was found for the second deviation to the four-cell stage, as expressed by the twofold higher proportion of two-cell stage embryos versus four-cell stage embryos at $42 \mathrm{~h}$ post fertilization. Early stages of embryonic development are key parameters in predicting which embryos will have high developmental competence. Early cleavage and the time of the first mitotic division are considered to be indicative of embryo quality, in particular of whether the embryo is transferable (Hasler et al. 1995, Shoukir et al. 1997, Sakkas et al. 1998) or competent to survive cryopreservation (Hasler et al. 1995, Van Montfoort et al. 2004). Indeed, the timing of the first divisions (Shoukir et al. 1997, Sakkas et al. 1998) and of the formation of an eight-cell embryo (Edwards et al. 1984) or blastocyst (Shoukir et al. 1998, Schwarzler et al. 2004) are used as valuable means of narrowing the number of embryos selected for transfer or cryopreservation. It has been reported that embryo evaluation based on sequential assessment, which takes several development stages into account, appears to be superior to the selection of the best embryos at a specific time point (Gardner \& Sakkas 2003, Neuber et al. 2003). Therefore, the delayed cleavage timing noted in the current study throughout the hot season might suggest a seasonal reduction in oocyte developmental competence.

A recent study in which the time-lapse system EmbryoGuard was used to determine the accurate cleavage timing of mouse embryos suggested that the time of the first embryonic cleavage to the two-cell stage, rather than further embryonic divisions, predicts developmental competence of embryos (Arav et al. 2008). The time-lapse system facilitates continuous noninvasive monitoring of embryos while maintaining them under optimal culture conditions in the incubator. Use of this system in the current study made it possible to collect accurate data on cleavage timing of the entire embryo population without examining embryos at subjectively selected time points, as performed in Exp. 1. In vitro studies have shown a clear relationship between early cleavage and developmental competence of bovine embryos (Lonergan et al. 1999). It has also been demonstrated that early-cleaved embryos have significantly higher cell numbers and better embryo morphology (van Soom et al. 1997, Rieger et al. 1999). Use of the EmbryoGuard system enabled us to accurately define the time at which bovine oocytes are cleaved. Cleavage to the two-cell stage was found to occur in two distinct waves: early cleavage occurred between 18 and $25 \mathrm{~h}$ post activation and late cleavage occurred between 26 and $42 \mathrm{~h}$ post activation. Although the experiment was performed only during the hot season, the

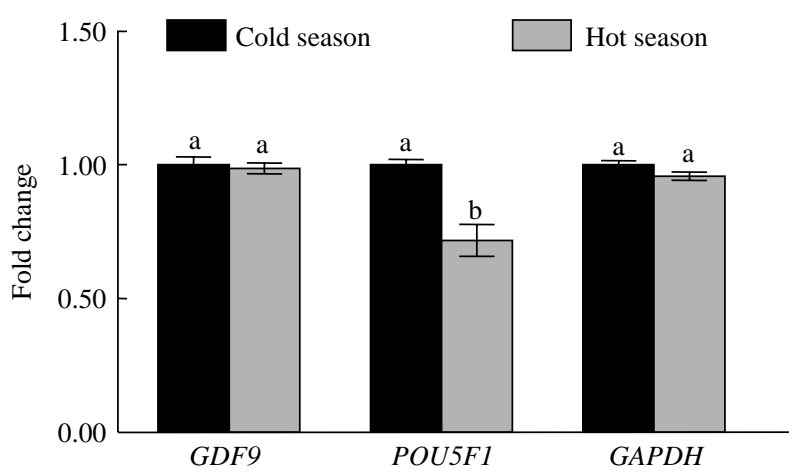

Figure 7 Transcript levels of GDF9, POU5F1, and GAPDH in early-cleaved embryos. Data from real-time PCR of two-cell stage embryos collected $27 \mathrm{~h}$ post fertilization in both cold (Dec-Apr) and hot (Jun-Sep) seasons are presented as means \pm s.E.M.; ${ }^{a, b}$ different superscripts indicate seasonal effect within genes, $P<0.05$. 
information was highly valuable in collecting early- and late-cleaved embryos to examine seasonal effects on gene expression (Exp. 3).

Our results provided evidence of higher gene expression (GAPDH, GDF9, and POU5F1) in earlyversus late-cleaved embryos, in both cold and hot seasons, suggesting a differential pattern of maternal gene expression which is tightly associated with cleavage timing. GAPDH is one of the most common 'housekeeping' genes, widely used to normalize gene data in various procedures, including quantitative and real-time PCR. Nevertheless, it has recently been reported that the transcription levels of GAPDH vary among cell types (Barber et al. 2005), developmental stages (Robert et al. 2002), and experimental conditions (Ito et al. 1996, Zhong \& Simons 1999), emphasizing the need to validate housekeeping genes for each examination. In the current study, two genes were considered for use as the internal control gene, GAPDH, and 185 $r R N A$. Our findings indicated that whereas the expression of $18 S$ rRNA was stable, that of GAPDH differed between early- and late-cleaved embryos, with a lower level in the latter. This was true for both hot and cold seasons. Similarly, Mamo et al. (2007) showed higher expression of GAPDH in early- versus latecleaved in vivo derived mouse embryos. However, Dode et al. (2006) reported constant expression of GAPDH in early- and late-cleaved bovine embryos. GAPDH plays a key role in energy metabolism. It is one of the enzymes that catalyze reactions in the glycolytic pathway, in particular converting glyceraldehyde-3phosphate to 1,3-diphosphoglycerate (Sirover 1999). GAPDH also plays a role in cellular functions which are not related to glycolysis. These include membrane fusion (Robbins et al. 1995, Hessler et al. 1998), DNA repair (Baxi \& Vishwanatha 1995), nuclear RNA export (Zhang \& Snyder 1992, Singh \& Green 1993), cytoskeletal organization (Launay et al. 1989, Walsh et al. 1989), phosphotransferase activity (Kawamoto \& Caswell 1986, Engel et al. 1998), and apoptosis (Ishitani \& Chuang 1996, Ishitani et al. 1997, Tajima et al. 1999). Therefore, reduced GAPDH expression or, alternatively, alterations in one or more of these GAPDH activities might underlie the reduced developmental competence of late-cleaved embryos. This, might explain, at least in part, the reduced developmental competence of bovine oocytes during the hot season.

Reduced expression of GDF9 was also noted for latecleaved two-cell stage embryos in both hot and cold seasons. Studies of mutant mice (Dong et al. 1996, Carabatsos et al. 1998) and GDF9-modified sheep (Hanrahan et al. 2004) have indicated that GDF9 plays an important role in the stimulation of early follicular growth. Female mice lacking a functional GDF9 gene were infertile and characterized by arrested follicular growth at the primary stage (Dong et al. 1996). In fact, GDF9 transcript is highly expressed in immature oocytes while they are enclosed in antral follicles, but decreases throughout early embryonic development, with only trace levels at the eight-cell stage (Pennetier et al. 2004). Therefore, it is suggested that seasonally induced alterations in GDF9 expression are involved in the reduced developmental competence noted for oocytes collected in the hot season. GDF9 is involved in the regulation of both oocyte and granulosa cell function at a very early stage of follicular development in rats (Vitt et al. 2000). In cattle and sheep, GDF9 mRNA is expressed in the primordial and subsequent stages of developing follicles (Bodensteiner et al. 1999). GDF9 has also been defined as a mitogenic factor since it stimulates proliferation of theca cells derived from small follicles of bovine (Spicer et al. 2008). Thus, it is possible that the seasonally induced alteration in GDF9 expression in the ovarian pool of follicles and/or their enclosed oocytes, as observed here, underlies the immediate and carry-over effect of summer thermal stress on follicular function and oocyte developmental competence recently reported for bovine (Roth et al. 2008). Likewise, maturation of mouse oocytes with exogenous GDF9 improves further embryonic development and fetal viability (Yeo et al. 2007). While not examined here, impairment in the cooperative functioning of TGFB superfamily proteins, bone morphogenetic protein 15, with GDF9 to maintain cumulus-oocyte complexes (COCs) integrity cannot be ruled out (Su et al. 2004).

Interestingly, while the expressions of GAPDH and GDF9 did not differ among the subpopulation of earlycleaved embryos, those that developed during the hot season expressed lower levels of POU5F1. POU5F1 is known to activate or repress the transcription of various target genes, such as FGF4, ZPF42 (REX-1), SPP1 (OPN), UTF1, $h C G$, and IFNT, during early embryonic development (Curatola \& Basilico 1990, Liu \& Roberts 1996, Liu et al. 1997, Ben-Shushan et al. 1998, Botquin et al. 1998, Nishimoto et al. 1999, Ezashi et al. 2001). Up- or downregulation of POU5F1 can induce changes in developmental programs (Niwa et al. 2000). In mice, ablation of POU5F1 causes early embryonic lethality, since blastomeres are differentiated to trophectoderm rather than to inner cell mass (ICM; Nichols et al. 1998), indicating involvement of POU5F1 in the establishment of pluripotency. POU5F1 also plays a role in maintaining mammalian germline viability since primordial germ cells lacking POU5F1 expression have been shown to undergo apoptosis instead of differentiation (Kehler et al. 2004). A critical amount of POU5F1 protein is required to sustain embryonic stem cells: increasing its expression by less than twofold causes differentiation into primitive endoderm and mesoderm. Reparation of POU5F1 induces loss of pluripotency and dedifferentiation to trophectoderm (Niwa et al. 2000). In in vitro derived bovine embryos, POU5F1 transcription is expressed throughout the early developmental stages of preimplantation embryos with high expression in immature 
oocytes up to the four-cell stage, followed by downregulation from the eight-cell stage to the morula, and relatively higher transcript at the blastocyst stage (Nganvongpanit et al. 2006). In contrast to mice (Palmieri et al. 1994, Kircof et al. 2000) and humans (Hansis et al. 2000), in bovine and porcine embryos, POU5F1 is not restricted to the ICM: it is present in both the ICM and the trophectoderm (Kircof et al. 2000). Taken together, low expression of POU5F1 in latecleaved embryos supports the assumption that these embryos are of inferior quality. Furthermore, seasonal alteration in POU5F1 in early-cleaved embryos might explain, in part, the decrease in blastocyst development observed in the hot season (current study) and the concomitant reduced reproductive performance of dairy cows (Al-Katanani et al. 2002). In addition, POU5F1 plays a role as an anti-apoptotic factor (Guo et al. 2007), and therefore, a reduction in POU5F1 expression might impair the balance between pro- and anti-apoptotic factors, which in turn might lead to increased apoptotic cells upon heat stress, as previously reported for bovine oocytes and pre-implantation embryos (Roth \& Hansen 2004a, 2004b).

In summary, delayed embryo cleavage was prominent during the hot season, indicating that during the summer, a high proportion of oocytes are of low developmental competence. Development and growth of embryos depend upon maternal mRNA and proteins stored in the oocyte. Thus, it is reasonable to assume that heatinduced alteration in the ovarian pool of oocytes affects the expression pattern of genes involved in early embryonic development, which in turn leads to a high proportion of late-cleaved embryos and reduced blastocyst formation.

\section{Materials and Methods}

All chemicals, unless otherwise specified, were purchased from Sigma-Aldrich. FSH and the ovine pituitary extract Ovagen were purchased from ICP Bio (Auckland, New Zealand). TriZol reagent, superscript II, Dynabeads mRNA DIRECT kit and nonessential amino acids (NEAAs) were purchased from Invitrogen. RNasin oligo(dT) ${ }_{12-18}$, moloney murine leukemia virus (M-MLV) RT, dNTPs, and RQ1 RNasefree DNase were purchased from Promega. $5 \times$ TBE buffer (53 g of Tris base, $27.5 \mathrm{~g}$ of boric acid, and $20 \mathrm{ml}$ of $0.5 \mathrm{M}$ EDTA ( $\mathrm{pH}$ 8.0) and diethylpyrocarbonate (DEPC)-treated water were purchased from Biological Industries (Beit-Haemek, Israel). DyNAmo qPCR kit was purchased from Zotal (Espoo, Finland). Double distilled water was purchased from Merck, and the culture media HEPES-Tyrode's lactate (TL), SP-TL, and IVF-TL were prepared in our laboratory: HEPES-TL was supplemented with $0.3 \%(\mathrm{w} / \mathrm{v}) \mathrm{BSA}, 0.2 \mathrm{mM}$ sodium pyruvate, and $0.75 \mathrm{mg} / \mathrm{ml}$ gentamicin (HEPES-TALP); SP-TL was supplemented with $0.6 \%$ BSA, $1 \mathrm{mM}$ sodium pyruvate, and $0.2 \mathrm{mg} / \mathrm{ml}$ gentamicin (SP-TALP); IVF-TL was supplemented with $0.6 \%$ essential fatty acid-free BSA, $0.2 \mathrm{mM}$ sodium pyruvate, $0.05 \mathrm{mg} / \mathrm{ml}$ gentamicin, and $0.01 \mathrm{mg} / \mathrm{ml}$ heparin (IVF-TALP;
Parrish et al. 1986). Oocyte maturation medium (OMM) was made up of TCM-199 with Earle's salts supplemented with $10 \%$ $(\mathrm{v} / \mathrm{v})$ heat-inactivated FCS (Bio-Lab), $0.2 \mathrm{mM}$ sodium pyruvate, $50 \mu \mathrm{g} / \mu \mathrm{l}$ gentamicin, $1.32 \mu \mathrm{g} / \mathrm{ml}$ ovine $\mathrm{FSH}$, and $2 \mu \mathrm{g} / \mathrm{ml}$ estradiol; potassium simplex optimized medium (KSOM)

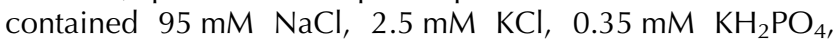
$0.2 \mathrm{mM} \mathrm{MgSO} \cdot \cdot 7 \mathrm{H}_{2} \mathrm{O}, 0.8 \%(\mathrm{v} / \mathrm{v})$ sodium lactate, $0.2 \mathrm{mM}$ sodium pyruvate, $0.2 \mathrm{mM} \mathrm{D}(+)$-glucose, $25 \mathrm{mM} \mathrm{NaHCO}$, $1 \mathrm{mM}$ L-glutamine, $0.01 \mathrm{mM}$ EDTA and $0.01 \mathrm{mM}$ phenol red supplemented with $1.7 \mathrm{mM} \mathrm{CaCl}{ }_{2} \cdot 2 \mathrm{H}_{2} \mathrm{O}, 0.1 \mathrm{mg} / \mathrm{ml}$ polyvinyl alcohol, $10 \mu \mathrm{l} / \mathrm{ml}$ essential amino acids and $5 \mu \mathrm{l} / \mathrm{ml} \mathrm{NEAAs,}$ $100 \mathrm{U} / \mathrm{ml}$ penicillin-G and $0.1 \mathrm{mg} / \mathrm{ml}$ streptomycin.

\section{In vitro production of embryos}

\section{Oocyte recovery and in vitro maturation}

Bovine ovaries were obtained from a local abattoir from multiparous Holstein cows during the hot and cold seasons, and transported to the laboratory in physiological saline solution $\left(0.9 \%(\mathrm{w} / \mathrm{v}) \mathrm{NaCl}\right.$ at $\left.37^{\circ} \mathrm{C}\right)$ with $50 \mu \mathrm{g} / \mathrm{ml}$ penicillinstreptomycin. The ovaries were transferred to the laboratory within 60-90 min, washed with fresh saline, cut through the center, and placed over a transillumination stand, so that follicles could be easily visualized (Arav 2001). COCs were aspirated from 3- to 8-mm follicles with an 18-gauge needle attached to a 10-ml syringe. COCs with at least three layers of cumulus surrounding a homogeneous cytoplasm were selected for further processing. After selection, COCs were washed three times in HEPES-TALP, and groups of ten oocytes were transferred into $50-\mu \mathrm{l}$ droplets of OMM overlaid with mineral oil. The droplets containing COCs were incubated in humidified air with $5 \% \mathrm{CO}_{2}$ for $22 \mathrm{~h}$ at $38.5^{\circ} \mathrm{C}$.

\section{Chemical activation of oocytes}

Activation was performed (Exp. 1 and Exp. 2) as previously described by Zeron et al. (2001). Matured oocytes were denuded from the cumulus cells and placed for $5 \mathrm{~min}$ in $2.47 \mu \mathrm{M}$ ionomycin dissolved in TCM-199 supplemented with $25 \mathrm{mM}$ HEPES, $10 \%$ (v/v) heat-inactivated FCS, $0.2 \mathrm{mM}$ sodium pyruvate, and $5 \mu \mathrm{g} / \mathrm{ml}$ gentamicin. Oocytes were then transferred to $2.45 \mu \mathrm{M}$ 6-dimethylaminopurine dissolved in TCM-199 for $4.5 \mathrm{~h}$ to prevent extrusion of the second polar body, thereby creating a diploid parthenogenetic embryo. Oocytes were washed three times in IVF cleavage medium (Cook, Sydney, Australia) and transferred in groups of 10 into $50-\mu$ l cleavage drops overlaid with mineral oil. Embryos were cultured at $38.5{ }^{\circ} \mathrm{C}, 5 \% \mathrm{CO}_{2}, 5 \% \mathrm{O}_{2}$, and $95 \%$ humidity (ThermoForma Model 3110, Thermo Scientific, Marietta, OH, USA).

IVF

Matured COCs were washed three times in HEPES-TALP and transferred in groups of 30 oocytes to four-well plates containing $600 \mu \mathrm{l} \mathrm{IVF-TALP}$ and $25 \mu \mathrm{l}$ of PHE $(0.5 \mathrm{mM}$ penicillamine, $0.25 \mathrm{mM}$ hypotaurine, and $25 \mu \mathrm{M}$ epinephrine in $0.9 \%(\mathrm{w} / \mathrm{v}) \mathrm{NaCl})$ per well and fertilized with $\sim 1 \times 10^{6}$ Percoll-purified spermatozoa from frozen-thawed semen. Spermatozoa were co-incubated with COCs for $18 \mathrm{~h}$ at $38.5{ }^{\circ} \mathrm{C}$ in a humidified atmosphere with $5 \% \mathrm{CO}_{2}$. 


\section{In vitro culture}

After fertilization, putative zygotes were removed from the fertilization wells, denuded of cumulus cells by gentle vortexing in HEPES-TALP containing $1000 \mathrm{U} / \mathrm{ml}$ hyaluronidase, and randomly placed in groups of 10 in a $25-\mu$ l droplet of KSOM. All embryo droplets were overlaid with mineral oil and cultured for 8 days at $38.5{ }^{\circ} \mathrm{C}$ in an atmosphere of humidified air with $5 \% \mathrm{CO}_{2}$ and $5 \% \mathrm{O}_{2}$.

\section{The EmbryoGuard system}

The EmbryoGuard system (IMT Ltd, Ness Ziona, Israel) is a robotic device enabling real-time monitoring of embryo dynamics without disturbing culture conditions, i.e. temperature, air composition, and humidity. It comprises an inverted microscope, charge-coupled device cameras, and a light source. The optical system is placed on a mobile optical table that can move along the $X$ and $Y$ axes as well as the $Z$ axis for focusing of all lenses. Embryos can be observed at three different magnifications: $4 \times, 200 \times$, and $1000 \times$. Automatic time-lapse photographs can be taken at specific preset intervals, and are saved in a database for subsequent analysis. The camera optics enable both automatic continuous timelapse photography and real-time microscopic observation of individual embryos (Arav et al. 2008). In the current study, the unit was programmed to collect images at 60-min intervals. Culture dishes were placed in the tissue-culture incubator maintained at $38.5{ }^{\circ} \mathrm{C}, 5 \% \mathrm{CO}_{2}$ in air and $95 \%$ humidity, in the EmbryoGuard unit. Embryos were observed for the occurrence of the first and second cleavages.

\section{Gene quantification}

\section{Sample collection}

Embryos were collected at specific cleavage times based on the EmbryoGuard data (Exp. 2): two-cell stage embryos collected at $27-28 \mathrm{~h}$ post fertilization were defined as early-cleaved embryos, while those collected at 42-43 h post fertilization were defined as late-cleaved embryos. For each group of embryos, four replicates were taken from different in vitro production runs, washed in PBS, snap frozen in liquid nitrogen, and stored at $-80{ }^{\circ} \mathrm{C}$ until RNA extraction. Each sample for RNA extraction contained ten embryos at the two-cell stage.

\section{Semi-quantitative RT-PCR}

Total RNA was extracted from each sample by TRIzol reagent according to the manufacturer's instructions (Invitrogen) with slight modifications. Briefly, $500 \mu$ l of TRIzol reagent with $1 \mu \mathrm{g}$ glycogen as the carrier were added to each sample. After centrifugation with chloroform $(100 \mu \mathrm{l})$, RNA was recovered (upper aqueous phase), precipitated with isopropanol, washed twice with ethanol, and dried for $5 \mathrm{~min}$. After extraction, the RNA pellet was resuspended in $8 \mu$ I DEPC water and treated with DNase I according to the manufacturer's instructions (Promega) to remove any DNA contamination. Isolated RNA was reverse-transcribed into cDNA in a total volume of $20 \mu \mathrm{l}$. The first step of the RT was incubation at $72{ }^{\circ} \mathrm{C}$ with $500 \mathrm{mg}$ oligo(dT) ${ }_{12-18}$ for $10 \mathrm{~min}$ followed by incubation for $60 \mathrm{~min}$ with RT mix, containing M-MLV RT, $5 \times$ M-MLV-RT buffer, $200 \mu \mathrm{M}$ dNTPs, $20 \mathrm{U}$ of RNasin, and $3 \mu \mathrm{l}$ of DEPC water. This mixture was incubated at $40{ }^{\circ} \mathrm{C}$ for $1 \mathrm{~h}$.

The cDNAs were used for separate PCR amplification with primer sets (10 $\mu \mathrm{M}$ each) for GDF9, POU5F1, GAPDH, and 185 $r R N A$ in a $25-\mu$ l reaction volume. The PCR program consisted of an initial denaturation step at $95{ }^{\circ} \mathrm{C}$ for 5 min followed by 35 cycles at $95{ }^{\circ} \mathrm{C}$ for $30 \mathrm{~s}, 55^{\circ} \mathrm{C}$ for $30 \mathrm{~s}, 72{ }^{\circ} \mathrm{C}$ for $30 \mathrm{~s}$, and a final extension at $72{ }^{\circ} \mathrm{C}$ for $10 \mathrm{~min}$. Primer sequences, size of the amplified products, and GenBank accession numbers are provided in Table 1 . The RT-PCR product $(18 \mu \mathrm{l})$ with $3 \mu \mathrm{l}$ of $6 \times$ loading buffer $(0.25 \%(\mathrm{w} / \mathrm{v})$ xylene cyanol and $25 \mathrm{mmol}$ EDTA/l in $50 \%(\mathrm{w} / \mathrm{v})$ glycerin) was loaded onto a $1.5 \%(\mathrm{w} / \mathrm{v})$ agarose gel in TBE buffer containing $0.2 \mu \mathrm{g} / \mathrm{ml}$ ethidium bromide. After electrophoresis at $80 \mathrm{~V}$ for $60 \mathrm{~min}$, the fragments were visualized on a 312-nm u.v. transilluminator. Scion-Image software (Frederick, MD, USA) was used to quantify the signal intensity of each band (data not shown).

\section{Real-time PCR}

Poly(A) RNA was isolated using Dynabeads mRNA DIRECT kit according to the manufacturer's instructions (Invitrogen). In brief, embryos were lysed by adding $100 \mu$ l lysis-binding buffer. Prewashed oligo $(\mathrm{dT})_{25}$ Dynabeads $(20 \mu \mathrm{l})$ were added to each

Table 1 Primers used in this study for semi-quantitative and real-time PCR.

\begin{tabular}{|c|c|c|c|c|}
\hline Genes & Primer & Accession number & Sequence $\left(5^{\prime} \rightarrow 3^{\prime}\right)$ & Size (bp) \\
\hline GDF9 & $\begin{array}{l}\text { Forward } \\
\text { Reverse }\end{array}$ & NM_174681 & $\begin{array}{l}\text { TGGTCCTTGCTGAAGCATCTAGA } \\
\text { ACAGTGTTGTAGAGGTGGCTTCT }\end{array}$ & 202 \\
\hline$G D F 9^{\mathrm{a}}$ & $\begin{array}{l}\text { Forward } \\
\text { Reverse }\end{array}$ & NM_174681 & $\begin{array}{l}\text { TGCACCTGTCTATGCCTTTG } \\
\text { AACATTTGGCCATGAGGAAG }\end{array}$ & 157 \\
\hline POU5F1 & $\begin{array}{l}\text { Forward } \\
\text { Reverse }\end{array}$ & AY490804 & $\begin{array}{l}\text { ATATACCCAGGCCGATGTGG } \\
\text { TGCACAAGGGTCTCTGCCTT }\end{array}$ & 201 \\
\hline GAPDH & $\begin{array}{l}\text { Forward } \\
\text { Reverse }\end{array}$ & U85042 & $\begin{array}{l}\text { CCAACGTGTCTGTTGTGGATCTGA } \\
\text { GAGCTTGACAAAGTGGTCGTTGAG }\end{array}$ & 237 \\
\hline $18 S$ rRNA & $\begin{array}{l}\text { Forward } \\
\text { Reverse }\end{array}$ & AF176811 & $\begin{array}{l}\text { GAGAAACGGCTACCACATCC } \\
\text { GGACACTCAGCTAAGAGCATCG }\end{array}$ & 337 \\
\hline $18 S r R N A^{\mathrm{a}}$ & $\begin{array}{l}\text { Forward } \\
\text { Reverse }\end{array}$ & AF176811 & $\begin{array}{l}\text { GGAGAGGGAGCCTGAGAAAC } \\
\text { TCGCGGAAGGATTTAAAGTG }\end{array}$ & 157 \\
\hline
\end{tabular}

\footnotetext{
${ }^{\text {a }}$ Primers used for real-time PCR.
} 
tube and mixed for $5 \mathrm{~min}$ at room temperature to allow binding of poly (A) to the beads. The samples were put into a magnetic separator to remove the lysis buffer while retaining the Dynabeads. The Dynabeads were washed twice with $100 \mu \mathrm{l}$ washing buffer A, twice with $100 \mu \mathrm{l}$ washing buffer B, and once with $100 \mu \mathrm{l} 10 \mathrm{mM}$ Tris- $\mathrm{HCl}$. After removal of Tris- $\mathrm{HCl}, 8 \mu \mathrm{l}$ of sterile DEPC water were added, and the samples were immediately subjected to RT.

RT was performed in a total volume of $20 \mu \mathrm{l}$. The first step was incubation at $70^{\circ} \mathrm{C}$ with $8 \mu \mathrm{l}$ RNA sample, $1 \mu \mathrm{l}$ oligo $(\mathrm{dT})_{12-18}(500 \mu \mathrm{g} / \mathrm{ml}), 1 \mu \mathrm{l}$ RNAseout, $1 \mu \mathrm{l}$ dNTPs $(10 \mathrm{mM}$ each), and $1 \mu \mathrm{l}(50 \mathrm{ng})$ random primer followed by 50-min incubation at $42{ }^{\circ} \mathrm{C}$ and $5 \mathrm{~min}$ at $70{ }^{\circ} \mathrm{C}$ with RT mix containing $4 \mu \mathrm{I} 5 \times \mathrm{RT}$ buffer, $200 \mathrm{U}$ of superscript II RT, $2 \mu \mathrm{l}$ $0.1 \mathrm{M}$ dithiothreitol, and DEPC water. The samples were transferred to $-20{ }^{\circ} \mathrm{C}$ until use.

Real-time PCR was conducted on an Mx3000p cycler (Stratagene, La Jolla, CA, USA) using SYBR green in a final volume of $20 \mu \mathrm{l}$ containing $3 \mu \mathrm{l}$ cDNA (equivalent to ten embryos at the two-cell stage) and $500 \mathrm{nM}$ of each primer. The amplification program included preincubation for taq polymerase activation at $95^{\circ} \mathrm{C}$ for $7 \mathrm{~min}$ followed by 40 amplification cycles of denaturation at $95^{\circ} \mathrm{C}$ for $10 \mathrm{~s}$ and annealing-elongation at $60^{\circ} \mathrm{C}$ for $15 \mathrm{~s}$. All samples were run in duplicate in 96-well plates. A melting curve analysis was recorded at the end of the amplification to confirm that there is no contamination by primer dimers. For each gene, standard curves were established using six serial dilutions of a reference cDNA. Fluorescence was acquired to determine the threshold cycle during the log-linear phase of the reaction at which fluorescence rose above background. Genes were quantified and analyzed by MxPRO QPCR Software for Mx3000p and Mx3005p QPCR ver 3, and the $\Delta \Delta C_{\mathrm{t}}$ method was used to calculate relative concentration of each gene which was expressed relative to $18 S$ rRNA.

\section{Experimental design}

A seasonal study was performed over three consecutive years. The first experiment was performed during the cold (Dec-Apr) and hot (May-Nov) seasons. Environmental data were obtained from the central meteorological station in Bet-Dagan, Israel. The maximum average air temperature and relative maximum humidity were $31.8 \pm 1.4{ }^{\circ} \mathrm{C}$ and $84.3 \pm 3.8 \%$ during the

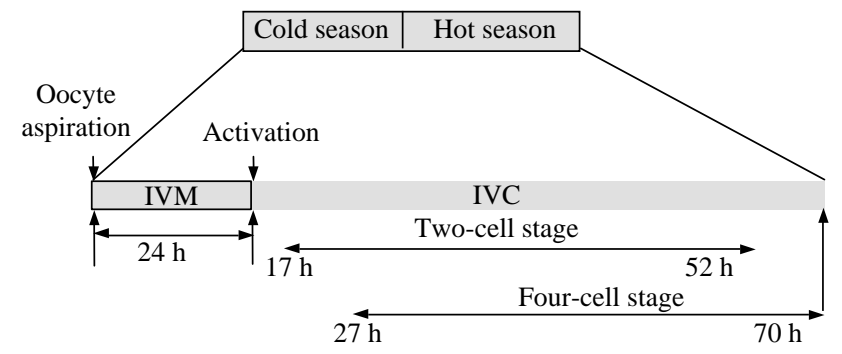

Figure 8 Schematic diagram of Exp. 1. The experiment was performed during the cold (Dec-Apr) and hot (May-Nov) seasons. Oocytes were in vitro matured (IVM), activated, and in vitro cultured (IVC).

Embryonic development to the two- and four-cell stages was recorded from 17 to $70 \mathrm{~h}$ post activation. summer, and $16.8 \pm 2.3^{\circ} \mathrm{C}$ and $46.0 \pm 15.0 \%$ during the winter respectively. Oocytes were aspirated from ovaries collected at the local abattoir, matured, activated, and in vitro cultured (Fig. 8). Early embryonic development with an emphasis on the rate of the two first deviations was recorded on $17,22,27,40,46,52,64$, and $70 \mathrm{~h}$ post activation. The time of developmental pick was defined as the time in which the highest proportion of developing embryos at a given stage was recorded. The second experiment was conducted during the hot season. Accurate timing of parthenos division was observed and documented with the EmbryoGuard system at 1-h intervals, to characterize the pattern of first cleavage of bovine embryos, as previously described by Arav et al. (2008). The third experiment was performed during both the cold (Dec-Apr) and hot (Jun-Sep) seasons. Oocytes were aspirated from ovaries collected at the local abattoir, matured, fertilized, and in vitro cultured as described above. The proportion of oocytes cleaved to the two- and four-cell stages and further developed to the blastocyst stage was assessed at 27, 42-44 h, and 8 days post fertilization respectively. Early- and latetwo-cell stage embryos were collected in each season (four experimental replicates, ten embryos each). Total RNA was isolated, and semi-quantitative PCR and real-time PCR were carried out with primers for GDF9, POU5F1, and GAPDH using $18 S \quad r R N A$ as the reference gene. The primers were derived from bovine sequences found in Genbank and designed using Primer Express software (Table 1).

\section{Statistical analysis}

Differences between treatments were subjected to one-way ANOVA (JMP-6; SAS Institute, Cary, NC, USA). $\chi^{2}$ test or Student's $t$-test was used to compare data among the experimental groups. Data are presented as mean \pm S.E.M. Relative gene expression was analyzed by one-way ANOVA followed by Tukey-Kramer test. Differences of $P<0.05$ were considered significant.

\section{Declaration of interest}

The authors declare that there is no conflict of interest that could be perceived as prejudicing the impartiality of the research reported.

\section{Funding}

This work was supported by the United State-Israel Binational Agricultural Research and Developmental Fund (BARD), project US-3986-07 and by USDA, grant 2007-35203-18073.

\section{Acknowledgements}

We are grateful to Dr Amir Arav for his excellent assistance with the time-lapse system and advice. Thanks to Mrs Chris Sebastian for her help in ovary collection. 


\section{References}

Al-Katanani YM, Paula-Lopes FF \& Hansen PJ 2002 Effect of season and exposure to heat stress on oocyte competence in Holstein cows. Journal of Dairy Science 85 390-396.

Arav A 2001 Transillumination increases oocyte recovery from ovaries collected at slaughter. A new technique report. Theriogenology $\mathbf{5 5}$ 1561-1565.

Arav A, Aroyo A, Yavin S \& Roth Z 2008 Prediction of embryonic developmental competence by time-lapse observation and 'shortest-half' analysis. Reproductive Biomedicine Online 17 669-675.

Aroyo A, Yavin S, Arav A \& Roth Z 2007 Maternal hyperthermia disrupts developmental competence of follicle-enclosed oocytes: in vivo and ex vivo studies in mice. Theriogenology 67 1013-1021.

Barber RD, Harmer DW, Coleman RA \& Clark BJ $2005 \mathrm{GAPDH}$ as a housekeeping gene: analysis of GAPDH mRNA expression in a panel of 72 human tissues. Physiological Genomics 21 389-395.

Baxi MD \& Vishwanatha JK 1995 Uracil DNA glycosylase/glyceraldehyde3-phosphate dehydrogenase is an Ap4A binding protein. Biochemistry 34 9700-9707.

Ben-Shushan E, James R, Thompson JR, Lorraine J, Gudas LG \& Bergman Y 1998 Rex-1, a gene encoding a transcription factor expressed in the early embryo, is regulated via Oct-3/4 and Oct- 6 binding to an octamer site and a novel protein, Rox-1, binding to an adjacent site. Molecular and Cellular Biology 18 1866-1878.

Bodensteiner KJ, Clay CM, Moeller CL \& Sawyer HR 1999 Molecular cloning of the ovine growth/differentiation factor-9 gene and expression of growth differentiation factor-9 in ovine and bovine ovaries. Biology of Reproduction 60 381-386.

Botquin V, Hess H, Fuhrmann G, Fuhrmann G, Anastassiadis C, Michael K, Gross MK, Vriend G \& Schöler HR 1998 New POU dimer configuration mediates antagonistic control of an osteopontin preimplantation enhancer by Oct-4 and Sox-2. Genes and Development 12 2073-2090.

Carabatsos MJ, Elvin J, Matzuk MM \& Albertini DF 1998 Characterization of oocyte and follicle development in growth differentiation factor9-deficient mice. Developmental Biology 204 373-384.

Curatola AM \& Basilico C 1990 Expression of the K-fgf proto oncogene is controlled by 38 regulatory elements which are specific for embryonal carcinoma cells. Molecular and Cellular Biology $102475-2484$.

Dode MA, Dufort I, Massicotte L \& Sirard MA 2006 Quantitative expression of candidate genes for developmental competence in bovine two-cell embryos. Molecular Reproduction and Development 73 288-297.

Dong J, Albertini DF, Nishimori K, Kumar TR, Lu N \& Matzuk MM 1996 Growth differentiation factor-9 is required during early ovarian folliculogenesis. Nature 383 531-535.

Edwards RG, Fishel SB, Cohen J, Fehilly CB, Purdy JM, Slater JM, Steptoe PC \& Webster JM 1984 Factors influencing the success of in vitro fertilization for alleviating human infertility. Journal of In Vitro Fertilization and Embryo Transfer 1 3-23.

Engel M, Seifert M, Theisinger B, Seyfert U \& Welter C 1998 Glyceraldehyde-3-phosphate dehydrogenase and Nm23-H1/nucleoside diphosphate kinase A: two old enzymes combine for the novel Nm23 protein phosphotransferase function. Journal of Biological Chemistry 273 20058-20065.

Ezashi T, Ghosh D \& Roberts RM 2001 Repression of Ets-2-induced transactivation of the tau interferon promoter by Oct-4. Molecular and Cellular Biology 21 7883-7891.

Gardner DK \& Sakkas D 2003 Assessment of embryo viability: the ability to select a single embryo for transfer - a review. Placenta 24 S5-S12.

Gui LM \& Joyce IM 2005 RNA interference evidence that growth differentiation factor-9 mediates oocyte regulation of cumulus expansion in mice. Biology of Reproduction 72 195-199.

Guo Y, Mantel C, Hromas R \& Broxmeyer HE 2007 OCT4 is critical for survival/antiapoptosis of murine embryonic stem cells subjected to stress. Effects associated with STAT3/Survivin. Stem Cells 26 30-34.

Hanrahan JP, Gregan SM, Mulsant P, Mullen M, Davis GH, Powell R \& Galloway SM 2004 Mutations in the genes for oocyte-derived growth factors GDF9 and BMP15 are associated with both increased ovulation rate and sterility in Cambridge and Belclare sheep (Ovis aries). Biology of Reproduction 70 900-909.
Hansis C, Grifo JA \& Krey LC 2000 OCT4 expression in inner cell mass and trophectoderm of human blastocysts. Molecular Human Reproduction 6 999-1004.

Hasler JF, Henderson WB, Hurtgen PJ, Jin ZQ, McCauley AD, Mower SA, Neely B, Shuey LS, Stokes JE \& Trimmer SA 1995 Production, freezing and transfer of bovine IVF embryos and subsequent calving results. Theriogenology 43 141-152.

Hessler RJ, Blackwood RA, Brock TG, Francis JW, Harsh DM \& Smolen JE 1998 Identifcation of glyceraldehyde-3-phosphate dehydrogenase as a $\mathrm{Ca}^{2+}$-dependent fusogen in human neutrophil cytosol. Journal of Leukocyte Biology 63 331-336.

Ishitani R \& Chuang DM 1996 Glyceraldehyde-3-phosphate dehydrogenase antisense oligodeoxynucleotides protect against cytosine arabinonucleoside-induced apoptosis in cultured cerebellar neurons. PNAS 93 9937-9941.

Ishitani R, Sunaga K, Tanaka M, Aishita H \& Chuang DM 1997 Overexpression of glyceraldehyde-3-phosphate dehydrogenase is involved in low $\mathrm{K}^{+}$-induced apoptosis but not necrosis of cultured cerebellar granule cells. Molecular Pharmacology 51 542-550.

Ito Y, Pagano PJ, Tornheim K, Brecher P \& Cohen RA 1996 Oxidative stress increases glyceraldehyde-3-phosphate dehydrogenase mRNA levels in isolated rabbit aorta. American Journal of Physiology $270 \mathrm{H} 81-\mathrm{H} 87$.

Kawamoto RM \& Caswell AH 1986 Autophosphorylation of glyceraldehydephosphate dehydrogenase and phosphorylation of protein from skeletal muscle microsomes. Biochemistry 25 656-661.

Kehler J, Tolkunova E, Koschorz B, Pesco M, Gentile L, Boiani M, Lomelí H, Nagy A, McLaughlin KJ, Schöler HR et al. 2004 OCT4 is required for primordial germ cell survival. EMBO Reports 5 1078-1083.

Kircof N, Carnwath JW, Lemme E, Anastassiadis K, Schöler H \& Niemann H 2000 Expression pattern of OCT4 in preimplantation embryos of different species. Biology of Reproduction 63 1698-1705.

Launay JFA, Jellali A \& Vanier MT 1989 Glyceraldehyde-3-phosphate dehydrogenase is a microtubule binding protein in a human colon tumor cell line. Biochimica et Biophysica Acta 996 103-109.

Liu L \& Roberts RM 1996 Silencing of the gene for the b subunit of human chorionic gonadotropin by the embryonic transcription factor Oct-3/4. Journal of Biological Chemistry 271 16683-16689.

Liu L, Leaman D, Villalta M \& Roberts RM 1997 Silencing of the gene for the alpha-subunit of human chorionic gonadotropin by the embryonic transcription factor Oct-3/4. Molecular Endocrinology 11 1651-1658.

Lonergan P, Khatir H, Piumi F, Rieger D, Humblot P \& Boland MP 1999 Effect of time interval from insemination to first cleavage on the developmental characteristics, sex ratio and pregnancy rate after transfer of bovine embryos. Journal of Reproduction and Fertility 117 159-167.

Mamo S, Gal AB, Bodo S \& Dinnyes A 2007 Quantitative evaluation and selection of reference genes in mouse oocytes and embryos cultured in vivo and in vitro. BMC Developmental Biology 6 7-14.

Masui Y 2001 From oocyte maturation to the in vitro cell cycle: the history of discoveries of maturation-promoting factor (MPF) and cytostatic factor (CSF). Differentiation 69 1-17.

McPherron AC \& Lee SJ 1993 GDF-3 and GDF-9: two new members of the transforming growth factor-beta superfamily containing a novel pattern of cysteines. Journal of Biological Chemistry 268 3444-3449.

Neuber E, Rinaudo P, Trimarchi JR \& Sakkas D 2003 Sequential assessment of individually cultured human embryos as an indicator of subsequent good quality blastocyst development. Human Reproduction 18 1307-1312.

Nganvongpanit K, Müller H, Rings F, Hoelker $M$, Jennen D, Tholen E, Havlicek V, Urban B, Schellander K \& Tesfaye D 2006 Selective degradation of maternal and embryonic transcripts in in vitro produced bovine oocytes and embryos using sequence specific double-stranded RNA. Reproduction 131 861-874.

Nichols J, Smith A \& Buehr M 1998 Rat and mouse epiblasts differ in their capacity to generate extraembryonic endoderm. Reproduction, Fertility, and Development 10 517-525.

Nishimoto M, Fukushima A, Okuda A \& Muramatsu M 1999 The gene for the embryonic stem cell coactivator UTF1 carries a regulatory element which selectively interacts with a complex composed of Oct-3/4 and Sox-2. Molecular and Cellular Biology 19 5453-5465.

Niwa H, Miyazaki J \& Smith AG 2000 Quantitative expression of Oct-3/4 defines differentiation, dedifferentiation or self-renewal of ES cells. Nature Genetics 24 373-376. 
Okamoto K, Okazawa H \& Okuda A 1990 A novel octamer binding transcription factor is differentially expressed in mouse embryonic cells. Cell 60 461-472.

Palmieri SL, Peter W, Hess H \& Schöler HR 1994 Oct-4 transcription factor is differentially expressed in the mouse embryo during establishment of the first two extraembryonic cell lineages involved in implantation. Developmental Biology 166 259-267.

Parrish JJ, Susko-Parrish JL, Crister ES, Eyestone WH \& First NL 1986 Bovine in vitro fertilization with frozen-thawed semen. Theriogenology 25 591-600.

Pennetier S, Uzbekova S, Perreau C, Papillier P, Mermillod P \& DalbièsTran R 2004 Spatio-temporal expression of the germ cell marker genes MATER, ZAR1, GDF9, BMP15 and VASA in adult bovine tissues, oocytes, and preimplantation embryos. Biology of Reproduction 71 359-366.

Rieger D, Lonergan P \& Boland MP 1999 The relationship between the time of first cleavage of fertilized cattle oocytes and their development to the blastocyst stage. Theriogenology 51190.

Robbins AR, Ward RD \& Oliver C 1995 A mutation in glyceraldehyde3-phosphate dehydrogenase alters endocytosis in $\mathrm{HO}$ cells. Journal of Cell Biology 130 1093-1104.

Robert C, McGraw S, Massicotte L, Pravetoni M, Gandolfi F \& Sirard MA 2002 Quantification of housekeeping transcript levels during the development of bovine preimplantation embryos. Biology of Reproduction 67 1465-1472.

Rocha A, Randel RD, Broussard JR, Lim JM, Blair RM, Roussel JD, Godke RA \& Hansel W 1998 High environmental temperature and humidity decrease oocyte quality in Bos taurus but not in Bos indicus cows. Theriogenology $49657-665$.

Roth Z \& Hansen PJ 2004a Involvement of apoptosis in disruption of developmental competence of bovine oocytes by heat shock during maturation. Biology of Reproduction 71 1898-1906.

Roth Z \& Hansen PJ 2004b Sphingosine 1-phosphate protects bovine oocytes from heat shock during maturation. Biology of Reproduction 71 2072-2078.

Roth Z, Meidan R, Braw-Tal R \& Wolfenson D 2000 Immediate and delayed effects of heat stress on follicular development and its association with plasma FSH and inhibin concentration in cows. Reproduction 120 83-90.

Roth Z, Arav A, Bor A, Zeron Y, Braw-Tal R \& Wolfenson D 2001 Improvement of quality of oocytes collected in the autumn by enhanced removal of impaired follicles from previously heat-stressed cows. Reproduction 122 737-744.

Roth Z, Inbar G \& Arav A 2008 Comparison of oocyte developmental competence and follicular steroid content of nulliparous heifers and cows at different stages of lactation. Theriogenology 69 932-939.

Ryan AK \& Rosenfeld MG 1997 POU domain family values: flexibility, partnerships, and developmental codes. Genes and Development 11 1207-1225.

Sakkas D, Shoukir Y, Chardonnens D, Bianchi PG \& Campana A 1998 Early cleavage of human embryos to the two-cell stage after intracytoplasmic sperm injection as an indicator of embryo viability. Human Reproduction 13 182-187.

Schwarzler P, Zech H, Auer M, Pfau K, Gobel G, Vanderzwalmen P \& Zech N 2004 Pregnancy outcome after blastocyst transfer as compared to early cleavage stage embryo transfer. Human Reproduction 19 2097-2102.

Shoukir Y, Campana A, Farley T \& Sakkas D 1997 Early cleavage of in-vitro fertilized human embryos to the 2-cell stage: a novel indicator of embryo quality and viability. Human Reproduction 12 1531-1536.

Shoukir Y, Chardonnens D, Campana A, Bischof P \& Sakkas D 1998 The rate of development and time of transfer play different roles in influencing the viability of human blastocysts. Human Reproduction 13 676-668.
Singh R \& Green MR 1993 Sequence-specifcity binding of transfer RNA by glyceraldehyde-3-phosphate dehydrogenase. Science 259 365-368.

Sirover MA 1999 New insights into an old protein: the functional diversity of mammalian glyceraldehyde-3-phosphate dehydrogenase. Biochimica et Biophysica Acta 1432 159-184.

Sonna LA, Fujita J, Gaffin SL \& Craig ML 2002 Molecular biology of thermoregulation invited review: effects of heat and cold stress on mammalian gene expression. Journal of Applied Physiology 92 1725-1742.

Spicer LJ, Aad PY, Allen DT, Mazerbourg S, Payne AH \& Hsueh AJ 2008 Growth differentiation factor 9 (GDF9) stimulates proliferation and inhibits steroidogenesis by bovine theca cells: influence of follicle size on responses to GDF9. Biology of Reproduction 78 243-253.

Su YQ, Wu X, O'Brien MJ, Pendola FL, Denegre JN, Matzuk MM \& Eppig JJ 2004 Synergistic roles of BMP15 and GDF9 in the development and function of the oocyte-cumulus cell complex in mice: genetic evidence for an oocyte-granulosa cell regulatory loop. Developmental Biology 276 64-73.

Tajima H, Tsuchiya K, Yamada M, Kondo K, Katsube N \& Ishitani R 1999 Over-expression of GAPDH induces apoptosis in COS-7 cells transfected with cloned GAPDH cDNAs. Neuroreport 10 2029-2033.

Van Montfoort AP, Dumoulin JC, Kester AD \& Evers JL 2004 Early cleavage is a valuable addition to existing embryo selection parameters: a study using single embryo transfers. Human Reproduction 19 2103-2108.

Van Soom A, Ysebaert MT \& de Kruif A 1997 Relationship between timing of development, morula morphology, and cell allocation to inner cell mass and trophectoderm in in vitro-produced bovine embryos. Molecular Reproduction and Development 47 47-56.

Vitt UA, Hayashi M, Klein C \& Hsueh AJ 2000 Growth differentiation factor9 stimulates proliferation but suppresses the follicle-stimulating hormone-induced differentiation of cultured granulosa cells from small antral and preovulatory rat follicles. Biology of Reproduction 62 370-377.

Walsh JL, Keith TJ \& Knull HR 1989 Glycolytic enzyme interactions with tubulin and microtubules. Biochimica et Biophysica Acta 999 64-70.

Wolfenson D, Roth Z \& Meidan R 2000 Impaired reproduction in heatstressed cattle: basic and applied aspects. Animal Reproduction Science 60-61 535-547.

Yeo CX, Gilchrist RB, Thompson JG \& Lane M 2007 Exogenous growth differentiation factor 9 in oocyte maturation media enhances subsequent embryo development and fetal viability in mice. Human Reproduction 23 67-73.

Yeom YI, Fuhrmann G, Ovitt CE, Brehm A, Ohbo K, Gross M, Hübner K \& Schöler HR 1996 Germline regulatory element of Oct-4 specific for the totipotent cycle of embryonal cells. Development 122 881-894.

Zeron Y, Ocheretny A, Kedar O, Borochov A, Sklan D \& Arav A 2001 Seasonal changes in bovine fertility: relation to developmental competence of oocytes, membrane properties and fatty acid composition of follicles. Reproduction $121447-454$.

Zhang J \& Snyder S 1992 Nitric oxide stimulates auto-ADP-ribosylation of glyceraldehyde-3-phosphate dehydrogenase. PNAS 89 9382-9385.

Zhong H \& Simons JW 1999 Direct comparison of GAPDH, beta-actin, cyclophilin, and 28S rRNA as internal standards for quantifying RNA levels under hypoxia. Biochemical and Biophysical Research Communications 259 523-525.

Received 1 February 2010

First decision 2 March 2010

Revised manuscript received 12 April 2010

Accepted 15 April 2010 